\title{
溶融錫中の亜鉛亡銀，銅，金亡の相互作用 係数について
}

\author{
萩原久人*，杉野重明*，高橋敏郎**
}

\section{1 緒言 (Introduction)}

溶融合金中の希薄成分間の相互作用係数の値は近年多 数の研究者汅より報告されている 銅, 銀, 金との相互作用係数については Tefelske $5^{2), 3)}$ の報告, 同じく要鉛と銀について Desré ら"の研究があ

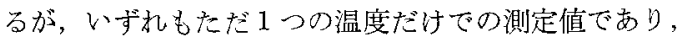
これらの系化ついて相互作用係数を温度の関数として測 定した研究はないよらである。著者らは錫を溶媒とし， 希薄亚鉛を主溶質とする合金溶液に希薄溶質Xを添加し た場合の相互作用倸数 $\varepsilon_{Z \mathrm{n}}^{\mathrm{x}}$ を系統的に求めるための一 環としてまず $\mathrm{X}=\mathrm{Ag}, \mathrm{Cu} ， \mathrm{Au}$ の場合について測定し た.

Wagner $^{5}$ は溶媒 1 中にいずれも希薄な溶質 $i, j, k$, 在含む多成分浴液中の戊分 $\mathrm{i}$ の活星保数 $\gamma_{\mathrm{i}}$ 次式の上 5に表した。

$$
\ln \gamma_{\mathrm{i}}=\ln \gamma_{\mathrm{i}}{ }^{\circ}+\varepsilon_{\mathrm{j}}{ }^{\mathrm{i}} N_{\mathrm{j}}+\varepsilon_{\mathrm{i}}{ }^{\mathrm{j}} N_{\mathrm{j}}+\varepsilon_{\mathrm{j}}{ }^{\mathrm{k}} N_{\mathbf{k}}
$$

ここに $\gamma_{\mathrm{i}}{ }^{\circ}$ 法溶媒 1 と溶質 $\mathrm{i}$ との 2 元系溶液中の $\mathrm{i} の$ 無限希橎状態括ける活量倸数， $\varepsilon_{\mathrm{i}}{ }^{\mathrm{i}}$ 汇同しくく2元系溶 液中の $\mathrm{i}$ の自己相互作用伱数， $\varepsilon_{\mathrm{i}}^{\mathrm{j}} ， \varepsilon_{\mathrm{i}}^{\mathrm{k}}$ はそれぞれ $\mathrm{i}-\mathrm{j}$ 閒， i-k 間の 3 元相互作用係数， $N_{\mathrm{i}}, N_{\mathrm{j}}, N_{\mathrm{k}}$ はを礼ぞ

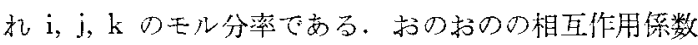
は次の上うに定義される。

$$
\begin{aligned}
& \varepsilon_{\mathrm{i}}{ }^{\mathrm{i}}=\left(\frac{\partial \ln \gamma_{\mathrm{i}}}{\partial N_{\mathrm{i}}}\right)_{N_{\mathrm{l}}=1,}, \\
& \varepsilon_{\mathrm{i}}{ }^{\mathrm{j}}=\left(\frac{\partial \ln \gamma_{\mathrm{i}}}{\partial N_{\mathrm{j}}}\right)_{N_{1}=1,} \\
& \varepsilon_{\mathrm{i}}{ }^{\mathrm{k}}=\left(\frac{\partial \ln \gamma_{\mathrm{i}}}{\partial N_{\mathrm{k}}}\right)_{N_{\mathrm{l}}=1,}
\end{aligned}
$$

（1）式は一般に希薄溶液の場合によく実験事実を表すこ とが知られている． 2 元系の測定から $r_{\mathrm{i}}^{\circ} ， \varepsilon_{\mathrm{i}}^{\mathrm{i}}$ を求め， 各種 3 元系の測定から $\varepsilon_{\mathrm{j}}{ }^{\mathrm{j}}, \varepsilon_{\mathrm{i}}{ }^{\mathrm{k}}$ を求为ると(1)式により, 多成分溶液中の成分 $\mathrm{i} の$ 活量係数が求まることになる。 本報の上うに3元系の場合惊（1）式は（3）式となる.

$$
\begin{aligned}
& \ln \gamma_{\mathrm{i}}=\ln r_{\mathrm{i}}{ }^{\circ}+\varepsilon_{\mathrm{i}}{ }^{\mathrm{i}} N_{\mathrm{i}}+\varepsilon_{\mathrm{i}}{ }^{\mathrm{j}} N_{\mathbf{j}} \\
& \ln \gamma_{\mathbf{Z}_{\mathbf{n}}}=\ln \gamma_{Z_{\mathrm{n}}}{ }^{\circ}+\varepsilon_{\mathbf{Z}_{\mathbf{n}}}^{Z_{\mathbf{n}}} N_{\mathbf{Z}_{\mathbf{n}}}+\varepsilon_{\mathbf{Z}_{\mathbf{n}}}^{\mathbf{x}} N_{\mathbf{x}}
\end{aligned}
$$

上述の上うに, $r_{Z_{\mathbf{n}}}{ }^{0}, \varepsilon_{Z_{\mathrm{n}}}^{Z_{\mathrm{n}}}$ は $\mathrm{Sn}-Z \mathrm{Zn} 2$ 元系の測定から 求まるものであるから， 3 元系を取り扱う前に $\mathrm{Sn}-\mathrm{Zn}$

\footnotetext{
* 大阪府立大工学部 (堺市百舌鳥梅町 4丁 804)
}

**大阪府立大学大学院（堺市百舌鳥梅町 4 丁 804)
2 元系の希薄监鉛の活量を正確に求少ておく必要が市 る. 本報では $S n-Z n 2$ 元系, $S n-Z n-X$ 元系溶液 (X $=\mathrm{Ag}, \mathrm{Cu}, \mathrm{Au})$ についての結果を報告するなお，亜鉛 の希薄な $\mathrm{Sn}-\mathrm{Zn} 2$ 元系の亜鉛の活量值についてはすで にいくつかの報告がある泫

\section{2 実験方法 (Experimental)}

実験方法は溶融塩を電解質とする起電力法によった。 用々た電池は

$\mathrm{Zn}(1)\left|\mathrm{ZnCl}_{2} \mathrm{in}(\mathrm{KCl}+\mathrm{LiCl})(1)\right| \mathrm{Sn}-\mathrm{Zn}$ or $\mathrm{Sn}-\mathrm{Zn}-\mathrm{X}(1)$ $(\mathrm{X}=\mathrm{Ag}, \mathrm{Cu}, \mathrm{Au})$ であり，電池反応注 $\mathrm{Zn}$ (pure liquid) $\rightarrow$ Zn(in liquid alloy) で, この電池の起電力を $E$ とし, 亚鉛の活量を $a_{\mathrm{Zn}}$ とすれば，

$$
\ln a_{\mathrm{Zn}}=-2 E F / R T
$$

な当関倸がある。ここに $F$ は Faraday 定数, $R$ 注気体 定数, $T$ は絶対温度である. (4) 式上り起電力 $E$ 索測 定すれば $a_{Z_{\mathrm{n}}}$ が求まる。本実験では液体純带鉛を活量の 基準にとる。

電池は内径 $1.3 \mathrm{~cm}$ のパイレックスガラス製 $\mathrm{H}$ 字管 で，3個の電池の各電極部が電気炉中で同一円周上に位 置するように招加机る。炉注全長 $40 \mathrm{~cm}$, 内径 $8.5 \mathrm{~cm}$ の二クロム炉で ON-OFF 式制御器（千野製）に上って 温度制御され，試料部分を $\pm 0.5^{\circ} \mathrm{C}$ の均熱帯に保持す る. 温度は較正された $\mathrm{CA}$ 熱電対を用いて測定し，その 精度は $\pm 0.5^{\circ} \mathrm{C}$ であった。起電力は電圧記録計（横河 製)で $0.01 \mathrm{mV}$ まで読みとった。電極金属扔よび合金 と反応性のないタングステン棒導線としてH字管の底 部に封入したＨ字管の一端㲹純亜鉛，他端飞組成既知 の合金を入れ，その上にあらかじめ精製した固型の電解 質を入れ，加熱しながら排気し十分に脱水後 $1 \times 10^{-5}$ $\mathrm{mmHg}$ の真空度で封じ切って測定仪供した。

電解質は市販特級の無水塩化カリウムと無水塩化リチ ウムとを重量比で 6:4 亿混合したものに $5 \mathrm{wt} \%$ の無 水塩化亜鉛を添加し，真空炉中約 $150^{\circ} \mathrm{C}$ て $2 \mathrm{~h}$ 乾燥後 $500^{\circ} \mathrm{C}$ で $2 \mathrm{~h}$ 溶解し，グラスウールでろ過して泠却凝固 させたものを使用した。

実験化供した錫，亜鉛，銀はいずれも $99.999 \%$ ，銅， 金沬 $99.99 \%$ 純度のもので, 試料合金は所定の組成に なるようにあらかじめ秤量配合したものをパイレックス 
Table 1 Electromotive force series in molten $\mathrm{LiCl}-\mathrm{KCl}$ eutectic melt at $450^{\circ} \mathrm{C}$ (After Laitinen and $\mathrm{Liu}^{11}$ )

\begin{tabular}{c|c}
\hline Electrode system & $E^{\circ} / \mathrm{V}$ \\
\hline $\operatorname{Zn}($ II $)-\operatorname{Zn}(0)$ & -1.566 \\
$\operatorname{Sn}(\mathrm{II})-\operatorname{Sn}(0)$ & -1.082 \\
$\operatorname{Cu}(\mathrm{I})-\mathrm{Cu}(0)$ & -0.851 \\
$\operatorname{Ag}(\mathrm{I})-\operatorname{Ag}(0)$ & -0.637 \\
$\operatorname{Pt}($ II $)-\operatorname{Pt}(0)$ & 0.009 \\
$\operatorname{Au}(\mathrm{I})-\operatorname{Au}(0)$ & 0.311 \\
\hline
\end{tabular}

管中に真空封入し $500^{\circ} \mathrm{C}$ で $\mathrm{Ih}$ よくかくはんしながら 溶解して作製した. $N_{Z_{\mathrm{n}}}$ が $0.02,0.04,0.06$ 亿相当寸 る2元系效よびこ礼らの扔の招のに $N_{\mathrm{x}}$ が $0.02,0.04$, 0.06 になる上うに各添加元素を加えた 3 元系合金につ いて $430^{\circ} \mathrm{C} \sim 610^{\circ} \mathrm{C}$ の温度範囲で起電力測定を行なっ た.

Laitinen $ら^{11)} 450^{\circ} \mathrm{C}$ における $\mathrm{KCl}-\mathrm{LiCl}$ 共晶溶 液中の白金電極を標準上した標準電極電位の值を報告し て掞り、こ机によって本奏験に関倸している元素の電位 を示すと Table 1 のごとくである. 亜鉛上他の金属上 の電溶圧の差が相当に大きいことがわかる，実際，測定 に当引可逆的な起電力值が得心れ，奏駼終了後の合金に は問題上なるような組成変化は生じていないこ上を化学 分析により確認した。

\section{3 実験 結 果 (Results)}

\section{$3.1 \mathrm{Sn}-\mathrm{Zn} 2$ 元系}

Table 2 Results of the least squares analyses of the experimental emf data for $\mathrm{Sn}-\mathrm{Zn}$ and $\mathrm{Sn}-\mathrm{Zn}-\mathrm{Ag}$ alloys, expressed as $E_{t}=E_{650}+(\mathrm{d} E / \mathrm{d} t)(t-450)$. $t$ : Temperature in ${ }^{\circ} \mathrm{C}$

\begin{tabular}{c|c|c|c|c|c}
\hline \hline$N_{\mathrm{Zn}}$ & $N_{\mathrm{Ag}}$ & $E_{450} / \mathrm{mV}$ & $(\mathrm{d} E / \mathrm{d} t) /\left(\mathrm{mV}^{\circ} \mathrm{C}^{-1}\right)$ & $\begin{array}{c}\text { Number of } \\
\text { measurements }\end{array}$ & $\begin{array}{c}\text { Correlation } \\
\text { coefficient }\end{array}$ \\
\hline \multirow{3}{*}{0.02} & 0.00 & $100.02 \pm 0.37$ & $0.2066 \pm 0.0048$ & 22 & 0.9988 \\
& 0.02 & $100.92 \pm 0.28$ & $0.2048 \pm 0.0032$ & 32 & 0.9991 \\
& 0.04 & $101.78 \pm 0.22$ & $0.2038 \pm 0.0028$ & 28 & 0.9994 \\
& 0.06 & $102.86 \pm 0.27$ & $0.2024 \pm 0.0030$ & 26 & 0.9994 \\
\hline \multirow{3}{*}{0.04} & 0.00 & $78.74 \pm 0.28$ & $0.1757 \pm 0.0035$ & 34 & 0.9985 \\
& 0.02 & $79.53 \pm 0.15$ & $0.1753 \pm 0.0018$ & 35 & 0.9996 \\
& 0.04 & $80.51 \pm 0.23$ & $0.1742 \pm 0.0027$ & 32 & 0.9991 \\
& 0.06 & $81.72 \pm 0.37$ & $0.1722 \pm 0.0048$ & 24 & 0.9981 \\
\hline \multirow{3}{*}{0.06} & 0.00 & $66.40 \pm 0.49$ & $0.1568 \pm 0.0058$ & 23 & 0.9967 \\
& 0.02 & $67.31 \pm 0.23$ & $0.1564 \pm 0.0027$ & 24 & 0.9992 \\
& 0.04 & $68.33 \pm 0.17$ & $0.1540 \pm 0.0020$ & 24 & 0.9996 \\
& 0.06 & $69.50 \pm 0.07$ & $0.1526 \pm 0.0009$ & 24 & 0.9999 \\
\hline
\end{tabular}

Errors shown are at the $95 \%$ confidence level. 


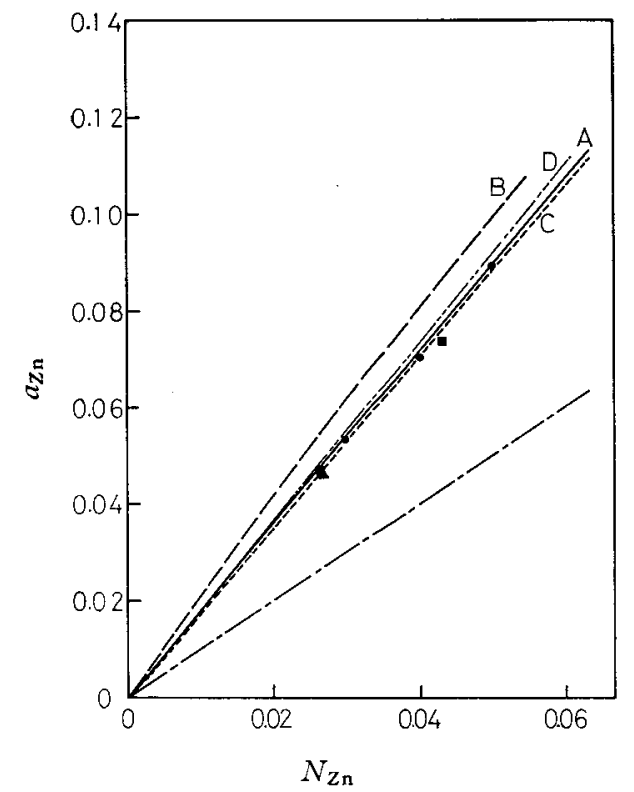

Fig. 2 Activity of zinc in $\mathrm{Sn}-\mathrm{Zn}$ alloys at $500^{\circ} \mathrm{C}$ A : This study, B : Chang et al., C : Calculated from Ref. 12, D : Moser, : Louvet et al., $\mathbf{\Delta}$ : Yokokawa et al., : Cleveland et al.

Temperature, $t^{\circ} \mathrm{C}$

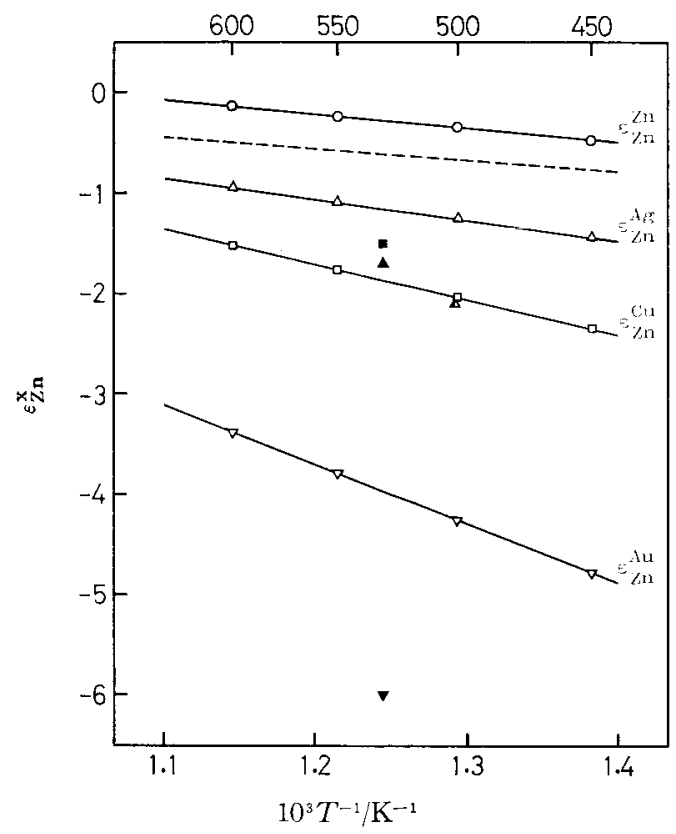

Fig. 3 Interaction parameters in liquid tin vs. reciprocal absolute temperature $\bigcirc, \triangle, \square, \nabla:$ This study,

Tefelske et al. ${ }^{2)}, \Delta:$ Desré et al. ${ }^{4)}$ --- $: \varepsilon_{Z_{n}}^{Z_{n}}$ calculated from Ref. 12
Table 3 Experimental values of limiting activity coefficient of zinc, $\ln \gamma_{Z_{n}}{ }^{\circ}$, and interaction parameters, $\varepsilon_{Z_{\mathbf{n}}}^{\mathrm{x}}$

\begin{tabular}{c|c|c|c|c|c}
\hline $\begin{array}{c}\text { Tem- } \\
\text { perature } \\
t /{ }^{\circ} \mathrm{C}\end{array}$ & $\ln r_{Z \mathrm{Zn}}^{\circ}$ & $\varepsilon_{\mathrm{Zn}}^{\mathrm{Zn}}$ & $\varepsilon_{\mathrm{Zn}}^{\mathrm{Ag}}$ & ${ }^{\varepsilon_{\mathbf{Z n}}^{\mathrm{Cu}}}$ & $\varepsilon_{\mathrm{Zn}}^{\mathrm{Au}}$ \\
\hline 450 & 0.708 & -0.461 & -1.43 & -2.34 & -4.78 \\
500 & 0.603 & -0.336 & -1.25 & -2.03 & -4.25 \\
550 & 0.511 & -0.227 & -1.09 & -1.75 & -3.79 \\
600 & 0.429 & -0.130 & -0.95 & -1.51 & -3.39 \\
\hline
\end{tabular}

温度が高くなるにつれてこの法則を示す線に近ずく。

Fig. 2 泣 $500^{\circ} \mathrm{C} に$ 扔ける $a_{2 \mathrm{n}}$ を従来の文献の值と比較し たものである。曲線 $\mathrm{A}$ は本実験值, 曲線 $\mathrm{B}$ は Chang ら7 の回転流出法による $498^{\circ} \mathrm{C}$ の結果, 曲線 $\mathrm{C}$ 江 Moser ${ }^{12}$ の論文中に与えられた Krupkowski の式からの計算值, 曲線 Dは Moser ${ }^{8}$ の起電力法によるもの, 印仙 Louvet

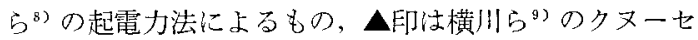
ンセル法 $\left(352^{\circ} \mathrm{C}\right)$ の結果 $500^{\circ} \mathrm{C}$ 一外挿した值，印

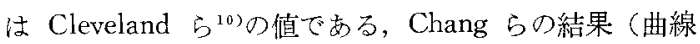
B) 以外は本実驗結果とよく一致している.

各温度に扝ける $\ln \gamma Z_{\mathrm{n}}$ と $N_{Z_{\mathrm{n}}}$ との関係加 $N_{\mathrm{Zn}_{\mathrm{n}}}=0$ における傾きを求めると，こ机らは(2)式汇よる $\varepsilon_{Z_{\mathrm{n}}}^{Z_{n}}$ の 值であり，史た $N_{Z_{\mathrm{n}}}=0$ に抬计る $\ln \gamma Z_{\mathrm{n}}$ の值が $\ln \gamma_{Z_{\mathrm{n}}}{ }^{\circ}$ となる、 $\varepsilon_{\mathrm{Zn}_{\mathrm{n}}^{\mathrm{n}}}^{\mathrm{n}}$ と $1 / T$ との関係を图示すると Fig. 3 のご とくであり，○印は本実験結果を表し，直線関倸が成立

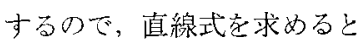

$$
\varepsilon_{Z_{\mathrm{n}}=1}^{Z_{\mathrm{n}}=1.462-1390 / T}
$$

となる、破線は、Moser ${ }^{12)}$ の論文から著者らが計算によ 门求めたもので, $\varepsilon_{Z_{\mathbf{n}}}^{Z_{n}}=0.825-1147 / T$ で表される. 彼 の值は本実験值と比較的近い值である. 本実験で求めた $\ln \gamma Z_{\mathrm{n}}{ }^{\circ}$ と $\varepsilon_{Z_{n}}^{Z n}$ の值を Table 3 に総括した。

\section{$3.2 \mathrm{Sn}-\mathrm{Zn}-\mathrm{Ag}$ 系}

測定された起電力と温度との関倸在 Fig. 4 に示寸. 図には最小二乗法による直線をひいてあるがよく測定值 を表している.最小二乗解析の結果を Table 2 に総括 して亦る. $450^{\circ} \mathrm{C}$ 上 $600^{\circ} \mathrm{C}$ に扔ける亜鉛の活量曲線を Fig. 5 亿示した。同一温度で $N_{\mathrm{Ag}}$ が増加すると $a_{Z \mathrm{n}}$ 注低下し，実験範囲内で法いずれも Raoult の法則から 正に偏倚しているが，温度上昇とともに次第に Raoult の法則線汇近づくことがわかる。銀が加わると $a_{Z \mathrm{n}}$ が 低ドすることは, $\mathrm{Ag}-\mathrm{Zn}$ 系状態図 ${ }^{13}$ に示されているよう に銀と而鉛との間の結合は強く種々の化合物が存在する ことからも予想されることである。

（2）式の定義により求めた相互作用係数 $\varepsilon_{\mathrm{Zn}}^{\mathrm{Ag}}$ と $1 / T$

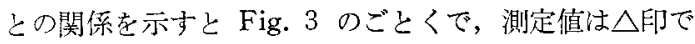
示すように直線上にのる.この直線式は 


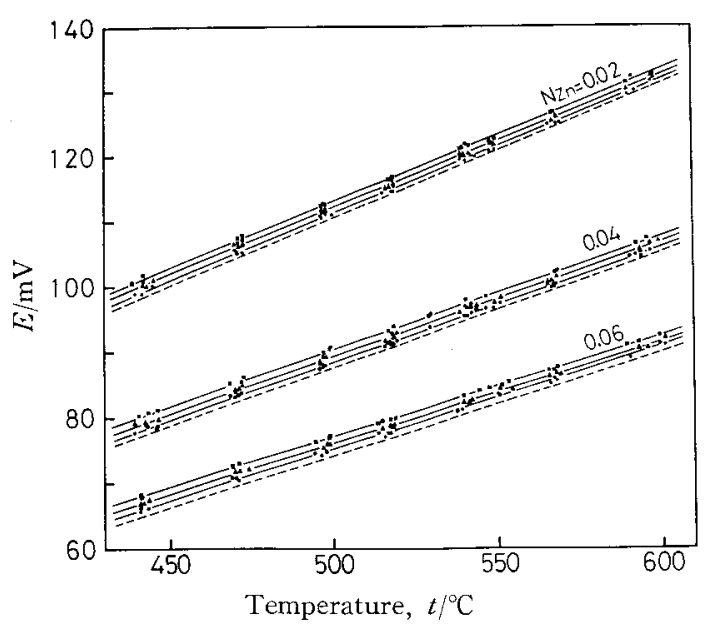

Fig. 4 Electromotive force-temperature relationship for $\mathrm{Sn}-\mathrm{Zn}-\mathrm{Ag}$ alloys . $: N_{\mathrm{Ag}}=0, \quad \mathbf{0}: 0.02$, $\mathbf{A}: 0.04, \mathbf{\square}: 0.06$

$$
\varepsilon_{Z_{\mathbf{n}}}^{\mathrm{Ag}}=1.381-2033 / T
$$

で表される。同図には Tefelske ら²) 印う，および Desré ら ${ }^{4}$ (メ印）の值ものせてあるが，本実験結果上 若干買なっている。車诸とも回転流出法によるものであ るが, Tefelske らは Desré らの結果老批判して, 測定 の際の試料全体の組成は蒸発が行なるれる表面組成上は 異なり，表面組成名もって表す心゙きだとし，Chang ら” の導出した溶質の濃度分布を表す式を用いて bulk と蒝 気との接触面に扔ける亜鉛濃度を求めている。しかしな がら，この補正式の中にはいくつかの仮定が含まれてお り，また相互作用係数の測定も単に1. 温度だけに限られ ているので Tefelske らの值の信頼度も不明である.

本実験で求めた各温度に扔ける $\varepsilon_{\mathrm{Zn}}^{\mathrm{Ag}}$ の值を Table 3

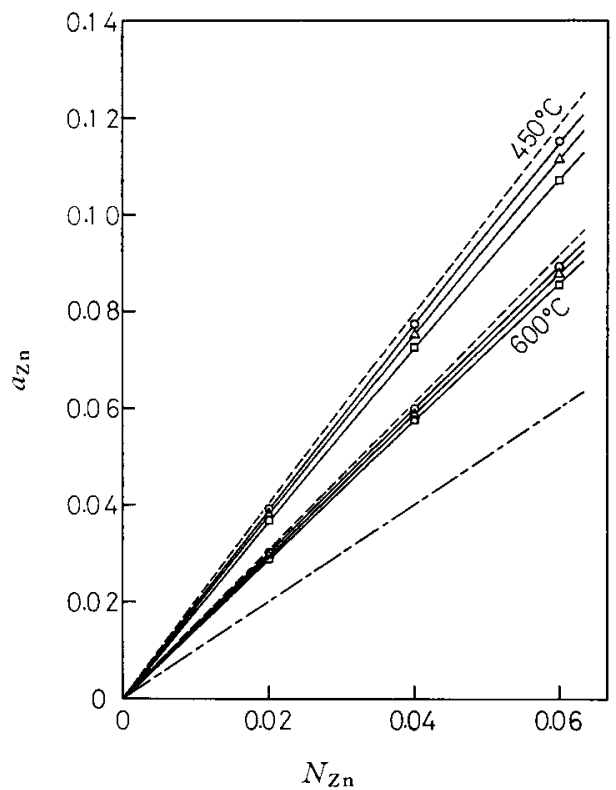

Fig. 5 Activity of zinc in $\mathrm{Sn}-\mathrm{Zn}-\mathrm{Ag}$ alloys at $450^{\circ} \mathrm{C}$ and $600^{\circ} \mathrm{C}$

$$
\begin{aligned}
& \square: 0.06 \\
& \square=0, \quad \bigcirc: 0.02, \triangle: 0.04,
\end{aligned}
$$

\section{にま上的た。}

\section{$3.3 \mathrm{Sn}-\mathrm{Zn}-\mathrm{Cu}$ 系}

起電力測定の結果を Table 4 に, 刺鉛の活量曲線を Fig. 6 亿示す. Sn-Zn 2 元系に銅を添加すると亜鉛の 活量が低下寸ることがわかる。. $\varepsilon_{Z n}^{\mathrm{Cu}}$ と $1 / T$ との関係は Fig. 3 の口印のように植線で表され，之の直線式は次の 上うになる。

$$
\varepsilon_{\mathbf{Z n}}^{\mathcal{C}_{\mathfrak{u}}}=2.461-3469 / T
$$

図に泣比較のため Tefelske ら゙による $\varepsilon_{Z n}^{\mathrm{Cu}}$ の値を口印

Table 4 Emf data for $\mathrm{Sn}-\mathrm{Zn}-\mathrm{Cu}$ alloys, as in Table 2

\begin{tabular}{c|c|c|c|c|c}
\hline \hline$N_{\mathrm{Zn}}$ & $N_{\mathrm{Cu}}$ & $E_{450} / \mathrm{mV}$ & $\left.(\mathrm{d} E / \mathrm{d} t) / \mathrm{mV}^{\circ} \mathrm{C}^{-1}\right)$ & $\begin{array}{c}\text { Number of } \\
\text { measurements }\end{array}$ & $\begin{array}{c}\text { Correlation } \\
\text { coefficient }\end{array}$ \\
\hline \multirow{3}{*}{0.02} & 0.02 & $101.43 \pm 0.22$ & $0.2049 \pm 0.0026$ & 24 & 0.9996 \\
& 0.04 & $102.94 \pm 0.22$ & $0.2026 \pm 0.0025$ & 33 & 0.9994 \\
& 0.06 & $104.37 \pm 0.40$ & $0.2005 \pm 0.0045$ & 30 & 0.9983 \\
\hline \multirow{3}{*}{0.04} & 0.02 & $80.10 \pm 0.35$ & $0.1733 \pm 0.0040$ & 32 & 0.9981 \\
& 0.04 & $81.63 \pm 0.21$ & $0.1718 \pm 0.0024$ & 24 & 0.9995 \\
& 0.06 & $83.02 \pm 0.46$ & $0.1696 \pm 0.0053$ & 24 & 0.9976 \\
\hline \multirow{3}{*}{0.06} & 0.02 & $67.85 \pm 0.48$ & $0.1548 \pm 0.0056$ & 28 & 0.9959 \\
& 0.04 & $69.36 \pm 0.24$ & $0.1531 \pm 0.0029$ & 24 & 0.9991 \\
& 0.06 & $70.70 \pm 0.34$ & $0.1510 \pm 0.0033$ & 25 & 0.9983 \\
\hline
\end{tabular}

Errors shown are at the $95 \%$ confidence level. 


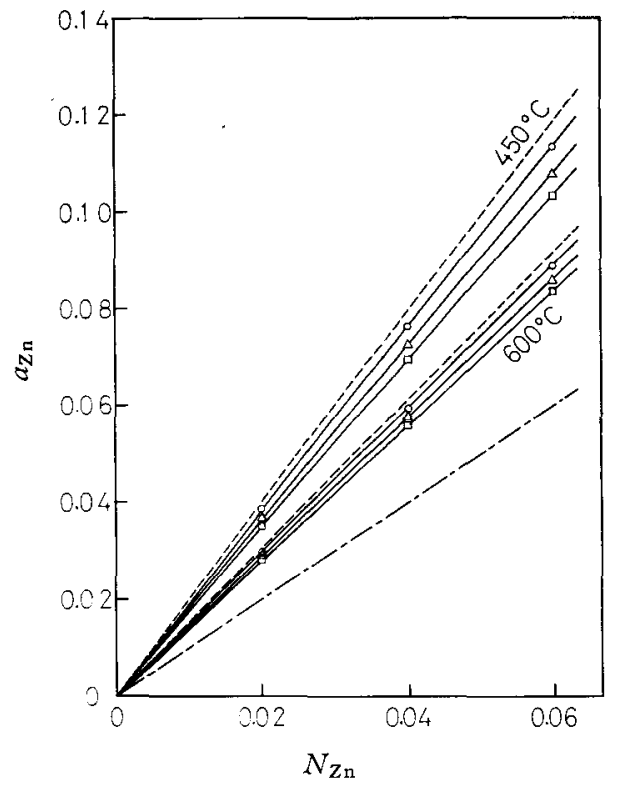

Fig. 6 Activity of zinc in $\mathrm{Sn}-\mathrm{Zn}-\mathrm{Cu}$ alloys at $450^{\circ} \mathrm{C}$ and $600^{\circ} \mathrm{C}$

$$
\ldots: N_{C_{u}}=0, \bigcirc: 0.02, \triangle: 0.04,
$$$$
\square: 0.06
$$

で示した. Table 3 に本実験による $\varepsilon_{Z_{n}}^{\mathrm{Cu}}$ の值を記した.

\section{$3.4 \quad \mathrm{Sn}-\mathrm{Zn}-\mathrm{Au}$ 系}

測定結果を Table 5 に示亦. 亜鉛の活量は $N_{\text {Au }}$ の 增加ととも低下するがその度合任銀，銅添加の場合と 比較して大きい (Fig. 7)， $\varepsilon_{Z_{\mathrm{n}}}^{\mathrm{Au}}$ と温度との関係を図示寸 ると Fig. 3 のマ印のごとくであり直線関係が成立つ. この直線式恔次式で表される。

$$
\varepsilon_{\mathrm{Zn}}^{\mathrm{Au}}=3.330-5863 / T
$$

図中の印は Tefelske ら ${ }^{3}$ による $\varepsilon_{\mathbf{Z} \mathbf{n}}^{\mathrm{Au}}$ の値である。本

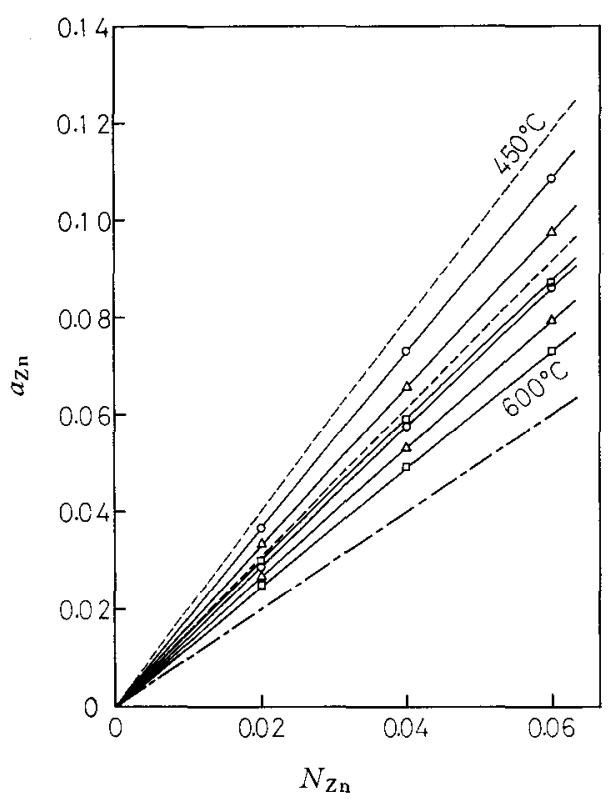

Fig. 7 Activity of zinc in $\mathrm{Sn}-\mathrm{Zn}-\mathrm{Au}$ alloys at $450^{\circ} \mathrm{C}$ and $600^{\circ} \mathrm{C}$ $-\cdots: N_{\text {Au }}=0, \bigcirc: 0.02, \triangle: 0.04$ $\square: 0.06$

実験による $\varepsilon_{Z \mathbf{n}}^{\mathrm{Auu}}$ の值を Table 3 にまとめた。

\section{4 考 察 (Discussion) \\ 4.1 Wagner $の$ 式の検討}

Table 3 の値を $\left(3^{\prime}\right)$ 式に代入して得られた各 3 元系 飞扮ける $\ln \gamma_{Z \mathrm{n}}$ の計算值と実测值との比較を Table 6 に示す。これによると全溶質濃度が $10 \mathrm{at} \%$ 以内の希薄 溶液の場合には両者はよく一致しており，Wagner の式 はこれら 3 元溶液中の亜鉛の活量係数をよく表すものと いえる。しかし全溶質濃度が 10 at \% 以上深なると次第

Table 5 Emf data for Sn-Zn-Au alloys, as in Table 2

\begin{tabular}{c|c|c|c|c|c}
\hline$N_{\mathrm{Zn}}$ & $N_{\mathrm{Au}}$ & $E_{450} / \mathrm{mV}$ & $(\mathrm{d} E / \mathrm{d} t) /\left(\mathrm{mV}^{\circ} \mathrm{C}^{-1}\right)$ & $\begin{array}{c}\text { Number of } \\
\text { measurements }\end{array}$ & $\begin{array}{c}\text { Correlation } \\
\text { coefficient }\end{array}$ \\
\hline \multirow{3}{*}{0.02} & 0.02 & $102.88 \pm 0.21$ & $0.2024 \pm 0.0024$ & 32 & 0.9994 \\
& 0.04 & $106.12 \pm 0.13$ & $0.2010 \pm 0.0016$ & 28 & 0.9998 \\
& 0.06 & $109.23 \pm 0.11$ & $0.1977 \pm 0.0013$ & 24 & 0.9999 \\
\hline \multirow{3}{*}{0.04} & 0.02 & $81.50 \pm 0.15$ & $0.1727 \pm 0.0019$ & 24 & 0.9997 \\
& 0.04 & $84.62 \pm 0.09$ & $0.1702 \pm 0.0011$ & 25 & 0.9999 \\
& 0.06 & $88.01 \pm 0.25$ & $0.1672 \pm 0.0031$ & 24 & 0.9991 \\
\hline \multirow{3}{*}{0.06} & 0.02 & $69.07 \pm 0.11$ & $0.1535 \pm 0.0014$ & 24 & 0.9998 \\
& 0.04 & $72.50 \pm 0.17$ & $0.1516 \pm 0.0022$ & 30 & 0.9993 \\
& 0.06 & $76.10 \pm 0.12$ & $0.1484 \pm 0.0015$ & 31 & 0.9997 \\
\hline
\end{tabular}

Errors shown are at the $95 \%$ confidence level. 
Table 6 Comparison of calculated and experimental activity coefficients of zinc in alloys at $500^{\circ} \mathrm{C}$

\begin{tabular}{|c|c|c|c|c|c|c|c|}
\hline \multicolumn{2}{|c|}{ Alloy composition } & \multicolumn{6}{|c|}{$\ln r_{2 n}$} \\
\hline \multirow{2}{*}{$N_{Z \mathrm{n}}$} & \multirow{2}{*}{$N_{\mathrm{x}}$} & \multicolumn{2}{|c|}{$\mathrm{Sn}-\mathrm{Zn}-\mathrm{Ag}$} & \multicolumn{2}{|c|}{$\mathrm{Sn}-\mathrm{Zn}-\mathrm{Cu}$} & \multicolumn{2}{|c|}{$\mathrm{Sn}-\mathrm{Zn}-\mathrm{Au}$} \\
\hline & & Exp. & Calc. & Exp. & Calc. & Exp. & Calc. \\
\hline \multirow{3}{*}{0.02} & 0.02 & 0.572 & 0.571 & 0.557 & 0.556 & 0.517 & 0.511 \\
\hline & 0.04 & 0.548 & 0.546 & 0.515 & 0.515 & 0.422 & 0.426 \\
\hline & 0.06 & 0.517 & 0.521 & 0.475 & 0.474 & 0.333 & 0.341 \\
\hline \multirow{3}{*}{0.06} & 0.02 & 0.556 & 0.558 & 0.542 & 0.542 & 0.508 & 0.498 \\
\hline & 0.04 & 0.529 & 0.533 & 0.499 & 0.502 & 0.407 & 0.413 \\
\hline & 0.06 & 0.496 & 0.508 & 0.462 & 0.461 & 0.304 & 0.328 \\
\hline
\end{tabular}

に一致の度合が悪くなるよらである。

\section{$4.2 \mathrm{Sn}-\mathrm{Zn}-\mathrm{X}$ 系 $(\mathrm{X}=\mathrm{Ag}, \mathrm{Cu}, \mathrm{Au})$ の希薄亜鉊の 活量およひ活量係数}

前述のごとく, Sn-Zn 2 元系汶対してこれら第 3 元素 を添加するといずれも亜鉛の活量を低下させるが，その 度合は銀，銅，金の順に大きくなる、著者らは以前に $1200 \mathrm{~K}$ に招ける $\mathrm{Cu}-\mathrm{Zn}, \mathrm{Ag}-\mathrm{Zn}$ 系の亜鉛の活量 ${ }^{14}$ を測 定した。これと Hultgren ら ${ }^{15}$ の $1048 \mathrm{~K}$ における Au $\mathrm{Zn}$ 采の活量を $1200 \mathrm{~K}$ の値に補正して Fig. 8 を得た。 これらの系の亜鉛の活量注いずれも Raoult の法則から 負に偏倚して扝り,負偏倚の度合は $\mathrm{Ag}-\mathrm{Zn}, \mathrm{Cu}-\mathrm{Zn}, \mathrm{Au}$ $\mathrm{Zn}$ 系の順以大きくなり，上述の溶質間の相互作用係数 の絶対值の大きさの順序と一致する.温度が多少変化し てもこの傾向は変らないものと考えられる。

Alcock と Richardson ${ }^{17}$ による random solution model によると 3 元相互作用係数の值法 2 元系の無限希 䣋に㧍ける活量倸数と関係があり, $\mathrm{Sn}-\mathrm{Zn}-\mathrm{Au}$ 系に適用 すると次のように表される。

$$
\varepsilon_{Z n}^{A u}=\ln \gamma_{Z n}{ }^{\circ}(A u)-\ln \gamma_{Z_{n}}{ }^{\circ}(S n)-\ln \gamma_{A u}{ }^{\circ}(S n)
$$

ここで $\gamma_{Z_{n}}{ }^{\circ}(\mathrm{Au}), r_{\mathrm{Z}^{\circ}}{ }^{\circ}(\mathrm{Sn})$ はそれぞれ $\mathrm{Au}-\mathrm{Zn}_{\mathrm{n}}$ 系, $\mathrm{Sn}-\mathrm{Zn}$ 系の亜鉛の無限希橎における活量係数であり， $\gamma_{\mathrm{Au}}{ }^{\circ}(\mathrm{Sn})$ は Sn-Au 系の金の無限希䐆における活量係数である.

著者らは $1048 \mathrm{~K}$ における Hultgren ら ${ }^{157}$ の金中の刺鉛 の活量保数の值を $N_{z_{\mathrm{n}}}=0$ 一外㧴して $\ln \gamma_{z_{\mathrm{n}}}{ }^{\circ}(\mathrm{Au})=$ 一8.15を得た。亦た Hultgren らによると $\ln \gamma_{\mathrm{Au}}{ }^{\circ}(\mathrm{Sn})$ の值は $600^{\circ} \mathrm{C}$ で $-4.96, \ln r_{2 n}{ }^{\circ}(\mathrm{Sn})$ は Table 3 から 同じく $609^{\circ} \mathrm{C}$ において 0.429 であるので, $\varepsilon_{\mathrm{Zn}}^{\mathrm{Au}}$ 㳉 -3.62 となる。一方本実験で得た $\epsilon_{\mathrm{Znn}}^{\mathrm{Au}}$ は $600^{\circ} \mathrm{C}$ でー3.39 だ あるのでよく一致するものといえる。しかしながら， $\ln r_{2 \mathrm{n}}{ }^{\circ}(\mathrm{Au})$ の值法高带鉛濃度側からの外雨值であり， かつ温度による $r_{z_{\mathrm{n}}}{ }^{\circ}(\mathrm{Au})$ の変化も無視しているので疑 問があり精確な值が望まれる。

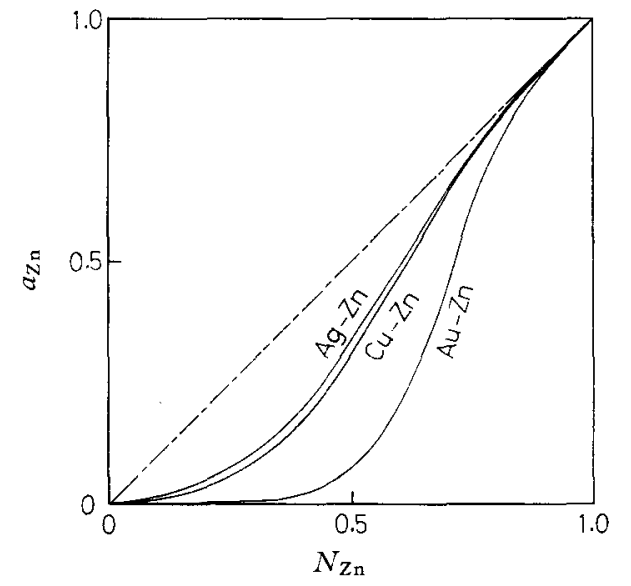

Fig. 8 Activity of zinc in $\mathrm{Ag}-\mathrm{Zn}, \mathrm{Cu}-\mathrm{Zn}$ and $\mathrm{Au}-\mathrm{Zn}$ systems at $1200 \mathrm{~K}$

Table 7 Interaction parameters of zinc in liquid tin alloys as a function of temperature

$\varepsilon_{\mathbf{Z}_{\mathbf{n}}}^{\mathrm{x}}=\mathrm{A}+\mathrm{B} / T$

\begin{tabular}{c|r|r|c|c}
\hline $\mathrm{X}$ & \multicolumn{1}{|c|}{$\mathrm{A}$} & \multicolumn{1}{c}{$\mathrm{B}$} & $\begin{array}{c}\text { Temperature } \\
t /{ }^{\circ} \mathrm{C}\end{array}$ & References \\
\hline $\mathrm{Bi}$ & 0.12 & 350 & $450-650$ & 8 \\
$\mathrm{In}$ & -0.53 & 758 & $441-532$ & 12 \\
$\mathrm{Cd}$ & -1.27 & 1367 & $441-604$ & 18 \\
$\mathrm{Zn}$ & 1.462 & -1390 & $430-610$ & This study \\
$\mathrm{Ag}$ & 1.381 & -2033 & $430-610$ & This study \\
$\mathrm{Cu}$ & 2.461 & -3469 & $430-610$ & This study \\
$\mathrm{Au}$ & 3.330 & -5863 & $430-610$ & This study \\
\hline
\end{tabular}

\section{$4.3 \operatorname{Sn}-\mathrm{Zn}-\mathrm{X}$ 系の $\varepsilon_{\mathrm{Zn}}^{\mathrm{X}}$ について}

$\mathrm{X}=\mathrm{Bi}$ については Louvet ら ${ }^{8)}$, Inについては Moser ${ }^{12)}$, Cd についてはPtak 上 Moser ${ }^{13)}$ の報告があり，いずれ も起電力法により亜鉛の活量を測定している。これらの 


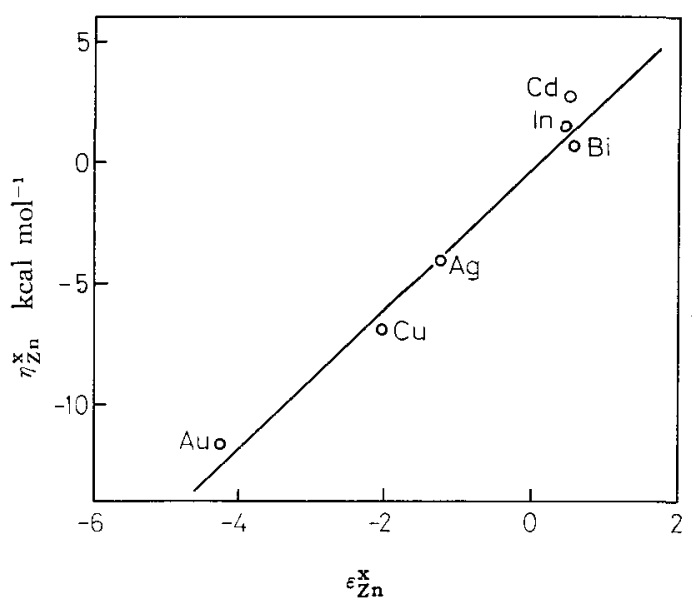

Fig. 9 Enthalpy parameter $\eta_{Z_{\mathrm{n}}}^{\mathrm{x}} v s$. interaction parameter $\varepsilon_{Z \mathbf{Z}}^{\mathrm{x}}$

元素は錫中の亜鉛の活量を増大させる，相互作用係数と 温度との関倸を $\varepsilon_{\mathrm{Zn}}^{\mathrm{x}}=\mathrm{A}+\mathrm{B} / T$ の形で一括して表すと Table 7 のごとくである.この表で In, Cd 亿ついての 值注文献の值から著者らが計算したものである。

さて，定義により $\left(\partial \ln r \mathrm{Zn} / \partial N_{\mathrm{x}}\right) N_{\mathrm{Sn}}=1=\varepsilon_{\mathrm{Zn}}^{\mathrm{x}}$ であるか らXが $N_{\mathrm{x}}$ だけ加わることによる溶質西鉛の部分モルギ ブスエネルギーの増加分を $\triangle \bar{G}_{Z_{\mathrm{n}}}^{\mathrm{x}}$ と和けば， $\triangle \bar{G}_{\mathrm{Zn}}^{\mathrm{x}}=$ $R T \varepsilon_{Z \mathbf{n}}^{\mathbf{x}} N_{\mathbf{x}}$ となる.これをエンタルピー項とエントロピ 一項とに分けると

$$
\begin{aligned}
\triangle \bar{G}_{Z \mathrm{n}}^{\mathrm{x}} & =R T \varepsilon_{Z \mathrm{n}}^{\mathrm{x}} N_{\mathrm{x}}=\Delta \bar{H}_{\mathbf{Z}_{\mathrm{n}}}^{\mathrm{x}}-T \triangle \bar{S}_{Z_{\mathrm{n}}}^{\mathrm{x}} \\
& =r_{Z_{\mathrm{Z}}}^{\mathrm{x}} N_{\mathrm{x}}-T \sigma_{\mathrm{Zn}}^{\mathrm{x}} N_{\mathrm{x}},
\end{aligned}
$$

河えに $\varepsilon_{\mathrm{Zn}}^{\mathrm{x}}=\eta_{Z_{\mathrm{n}}}^{\mathrm{x}} / R T-\sigma_{\mathrm{Zn}}^{\mathrm{x}} / T$ 上なる.上にあげた $\mathrm{Sn}-$ $\mathrm{Zn}-\mathrm{X}$ 系ではいずれの場合も $\varepsilon_{\mathrm{Zn}}^{\mathrm{x}}=\mathrm{A}+\mathrm{B} / \mathrm{T}$ の形で表さ れるのでエンタルピー項を表す $n_{Z \mathrm{n}}^{\mathrm{x}}$ は $R \mathrm{~B}$ ，エントロピ

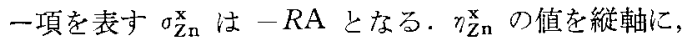
横軸に $\varepsilon_{\mathrm{Zn}}^{\mathrm{x}}$ とって示せば Fig. 9 のようにこれらの元 素は 1 つの直線上に位置する. ᄂか子両軸の $(0,0)$ を 通る直楾でほぼ表されることがわかる。このことは Fe$\mathrm{N}-\mathrm{X}$ 系, $\mathrm{Cu}-\mathrm{S}-\mathrm{X}$ 系, $\mathrm{Cu}-\mathrm{O}-\mathrm{X}$ 系などにおいて成立つ16) ことが知られているが，溶媒，溶質ともに金属元素であ る本系においてこのようなことが成立つことは興味深い ことであり，その他のXについても同様なことが成立つ かどらかはこ礼からの研究に待ちたい，次化ントロピ 一項の $\sigma_{\mathrm{Zn}}^{\mathrm{x}}$ をエンタルビー項の $\eta_{Z \mathrm{n}}^{\mathrm{x}}$ に対してプロット すると Fig. 10 のご上くになり両者は大体直線関係沉あ る.ここで求めた $\eta_{\mathrm{Zn}}^{\mathrm{x}}$ と $\sigma_{\mathrm{Zn}}^{\mathrm{x}}$ の值は単にある温度範囲 内での活量の測定結果から得られたものであるから正確 な值と注いえないかも知れないが，負の大きなエンタル ピー項は負の大きなエントロピー項と対応していること

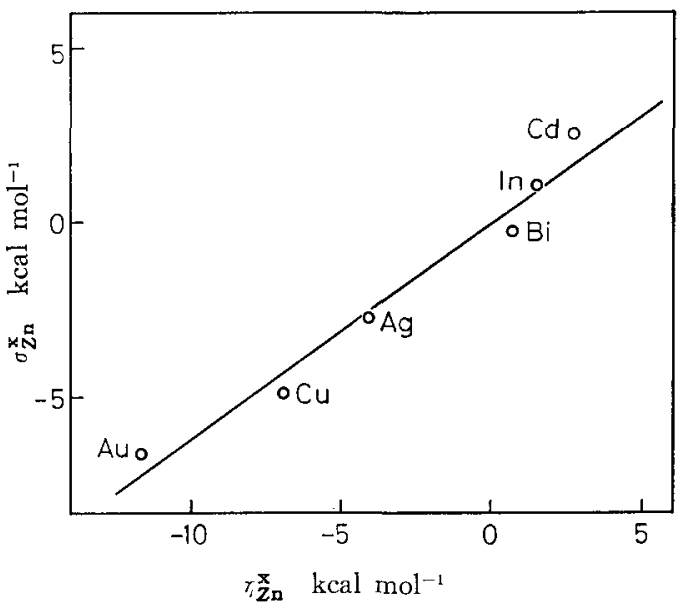

Fig. 10 The relation between enthalpy and entropy parameters

がわかる.

Fig. 9, Fig. 10 ともに Sn-Zn-Cd 系だけは直線から やや外れているが，この原因江主として起電力測定の際 に起る置換反応に上るのであるうと考えら机る. Moser $ら^{6), 19}$ 泣亜鉛が非常に希薄な $\mathrm{Zn}-\mathrm{Cd}$ 合金極上電解質中 の $\mathrm{ZnCl}_{2}$ との閒で $\mathrm{ZnCl}_{2}+\mathrm{Cd} \cdots \mathrm{CdCl}_{2}-\mathrm{Zn}$ なる反応 が 714 877 K で害際起っていること童認为ている。 $\mathrm{Sn}-\mathrm{Zn}-\mathrm{Cd}$ 系 ${ }^{18)}$ の場合はカドミウムが希薄な状態で溶媒 錫中に存在するのであるから条件仕暴なるのであるが上 述の上うな副反応加起っていることが十分考えられる。

亜鉛が希薄な $\mathrm{Sn}-\mathrm{Zn}$ 合金中の 1 at \% の金は $430^{\circ}$ $\sim 610^{\circ} \mathrm{C}$ の温度範囲で曲鉛の部分モルエンタルピーを一 $117 \mathrm{cal} \mathrm{mol}^{-1}$ だけ，また部分モルエントロピーをー0.07 cal mol ${ }^{-1} \mathrm{~K}^{-1}$ だけ変化させることになる．同様に銅，銀 については、エンタルピーをそれぞれー69,-40 $\mathrm{cal} \mathrm{mol}^{-1}$ だけ変化させ, エントロピーをそれぞれ $-0.05 \mathrm{cal} \mathrm{mol}^{-1}$ $\mathrm{K}^{-1},-0.03 \mathrm{cal} \mathrm{mol}^{-1} \mathrm{~K}^{-1}$ だけ変化させる.これらの值 は，たとえば $1200^{\circ} \mathrm{C}$ に括ける液体銅中の酸素に対する リンの挙動207などに比べるとはるかに小さいが，溶媒錫 中に希薄に存在する亜鉛原子の囲りに銅，銀，金などの 溶質原子がある程度会合しているものと考えられ，また それらの会合の度合注銀，銅，金の順序で大きくなるも のと考えられる.

\section{5 総括 (Summary)}

（1）起電力法を用いて $S n-Z n 2$ 元系および Sn-Zn$\mathrm{Ag}, \mathrm{Sn}-\mathrm{Zn}-\mathrm{Cu}, \mathrm{Sn}-\mathrm{Zn}-\mathrm{Au}$ 各 3 元系溶液中の亜鉛の活 量を $430^{\circ} \sim 610^{\circ} \mathrm{C}$ において測定し，その結果から溶質間 の相互作用係数を決定した。相互作用係数の值は絶対温 度の逆数汇対して直線的化変化し, 得られた結果は次式 で与えられる。

$$
\varepsilon_{Z_{\mathrm{n}}}^{\mathrm{Zn}}=1.462-1390 / T
$$




$$
\begin{gathered}
\varepsilon_{Z_{\mathrm{n}}}^{\mathrm{Ag}}=1.381-2033 / T, \\
\varepsilon_{Z_{\mathrm{n}}}^{\mathrm{Cu}}=2.461-3469 / T, \\
\varepsilon_{Z_{\mathrm{n}}}^{\mathrm{Au}}=3.330-5863 / T
\end{gathered}
$$

銀，銅，金ともに錫中の亜鉛の活量を低下させ，その度 合はこの順に大きくなる。

（2）本研究で求めた相互作用係数を用いて表した， Wagner の式による亜鉛の活量係数の值は，全溶質濃度 が約 10 at \% までは測定值とよく一致するが, 全溶質濃 度が $10 \mathrm{at} \%$ 以上になると一致の程度が悪くなる。

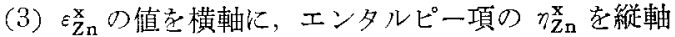
にとって表すとこの関係はほぼ 1 つ直線で表される。 同様なことがエンタルピー項を横軸に, エントロピー項

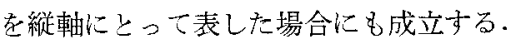

$<1744\rangle$ (Received Jan. 23, 1978)

\section{文献}

1) たとえ汭 J.M. Dealy and R.D. Pehlke, Trans. AIME, 227, 88 (1963).

2) T. Tefelske, Y.A. Chang and R.E. Miller, Met. Trans. 3, 2985 (1972).

3) T. Tefelske and Y.A. Chang, Mater. Sci. Eng. 14, 211 (1974).

4) P. Desré and É. Bonnier, J. Chim. Phys. Physicochim. Biol. 64, 1243 (1967).

5) C. Wagner, "Thermodynamics of Alloys", (1952), Addison-Wesley Press, Cambridge.

6) Z. Moser, Bull. Acad. Pol. Sci., Ser. Sci.Tech. 17, 467(1969).

7) Y.A. Chang, G.C. Wilhelm, M. Lathrop and I. Gyuk, Acta Met. 19, 795 (1971).

8) R.L. Louvet, J.V. Gluck and R.D. Pehlke, Trans. AIME. 242, 2369 (1968).

9) T. Yokokawa, A. Doi and K. Niwa, J. Phys. Chem. 65, 202 (1961).

10) S.T. Cleveland, K. Okajima and R.D. Pehlke, J. Phys. Chem. 69, 4085 (1965).

11) H.A. Laitinen and C.H. Liu, J.Amer. Chem. Soc. 80, 1015 (1958).

12) Z. Moser, Z. Metallkde. 65, 106 (1974).

13) M. Hansen and K. Anderko, "Constitution of Binary Alloys", (1958), McGraw-Hill, New York.

14）萩原久人，杉野重明，“日本金属学会昭和 44 年度秋期大 会满演概要集”, p. 193 (1969).
15) R. Hultgren, R.L. Orr, P.D. Anderson and K.K. Kelley, "Selected Values of Thermodynamic Properties of Metals and Alloys", (1963), John Wiley \& Sons, Inc. New York.

16) F.D. Richardson, "Physical Chemistry of Melts in Metallurgy", Vol. 1, (1974), Academic Press, London.

17) C.B. Alcock and F.D. Richardson, Acta. Met. 6, 385 (1958).

18) W. Ptak and Z. Moser, Bull. Acad. Pol. Sci., Ser. Sci. Tech. 18, 383 (1970).

19) Z. Moser and K. Fitzner, J. Electrochem. Soc. 120, 914 (1973).

20) K.T. Jacob and J.H.E. Jeffes, Trans. Inst. Mining Met. 80, C181 (1971).

$$
\text { ¿ }
$$

\section{Interaction Parameters of Zinc with Silver, Copper and Gold in Liquid Tin}

Hisato Hagrwara*, Shigeaki Sugino* and Toshiro TAKAHASHI** (*Faculty of Engineering, University of Osaka Prefecture; **Graduate School, University of Osaka Prefecture, 4-804, Mozu-Umemachi, Sakai)

Concentration cells of the type $\mathrm{Zn}(1) \mid \mathrm{ZnCl}_{2}$ in $(\mathrm{KCl}$ $+\mathrm{LiCl})(1) \mid \mathrm{Sn}-\mathrm{Zn}$ or $\mathrm{Sn}-\mathrm{Zn}-\mathrm{X}(1)(\mathrm{X}=\mathrm{Ag}, \mathrm{Cu}, \mathrm{Au})$ have been employed for a study of the thermodynamic activity of zinc in $\mathrm{Sn}-\mathrm{Zn}$ and $\mathrm{Sn}-\mathrm{Zn}-\mathrm{X}$ alloys between 430 and $600^{\circ} \mathrm{C}$, and for compositions up to 6 atomic percent of each solute.

The data were treated in terms of Wagner's linear relations. The interaction parameters obtained here are expressed as follows:

$$
\begin{aligned}
& \varepsilon_{\mathrm{Zn}}^{Z_{\mathrm{n}}}=1.462-1390 / T, \\
& \varepsilon_{\mathrm{Zn}}^{\mathrm{Ag}}=1.381-2033 / T, \\
& \varepsilon_{\mathrm{Zn}}^{\mathrm{Cu}}=2.461-3469 / T, \\
& \varepsilon_{\mathrm{Zn}}^{\mathrm{Au}}=3.330-5863 / T
\end{aligned}
$$

It was found that, within the limits of accuracy, the interaction parameter $\varepsilon_{Z_{\mathbf{n}}}^{\mathrm{x}}(\mathrm{X}=\mathrm{Cd}, \mathrm{In}, \mathrm{Bi}, \mathrm{Ag}, \mathrm{Cu}$ and $\mathrm{Au}$ ) in liquid tin is approximately expressed by a linear function with an enthalpy and a entropy parameters of the equation

$$
\triangle \bar{G}_{Z_{\mathrm{n}}}^{\mathrm{x}}=R T \varepsilon_{Z_{\mathbf{n}}}^{\mathrm{x}} N_{\mathrm{x}}=\eta_{Z_{\mathbf{n}}}^{\mathrm{x}} N_{\mathbf{x}}-T \sigma_{Z_{\mathrm{n}}}^{\mathrm{x}} N_{\mathbf{x}}
$$

